\title{
家庭部門における省エネルギー型給湯器の導入実態の分析 AN ANALYSIS OF THE ADOPTION OF ENERGY-EFFICIENT WATER HEATERS IN THE RESIDENTIAL SECTOR
}

\author{
元 アンナ*，西尾 健一郎**，岩船 由美子*** \\ Anna WON, Ken-ichiro NISHIO and Yumiko IWAFUNE
}

\begin{abstract}
The energy consumption for water heating accounts for approximately $30 \%$ of the energy required by the residential sector in FY 2007. Despite the high expectation of low CO2 emission, energy-efficient (EE) water heaters are not yet widely used. In this report, we aim to analyze and discuss the market of water heaters on the basis of a questionnaire survey. Firstly, the result shows that the adoption rate of $\mathrm{EE}$ water heaters is higher in the market of new custom-built detached houses than in that of new ready-made detached houses. However, the high initial cost of $\mathrm{EE}$ water heaters is likely a financial barrier, and also, customer preferences tend to be affected by builders' product lineup to some extent even in the case of custom-built detached houses. Secondly, the adoption rate is relatively high in the case of newly built apartments for sale, probably due to stiff market competition. Thirdly, concerning the replacement of water heaters in detached houses, the adoption rate of EE water heaters is relatively high, although there still remain barriers such as the high initial cost and influences of the lineup of products that sales channels deal. Finally, the replacement of water heaters in newly built apartments was difficult to change energy sources and types of water heater because of space and structure problems.
\end{abstract}

Keywords : Water heater, Energy efficiency, Technology diffusion barrier, Residential sector, Questionnaire survey, Market research 給湯器, 省エネルギー，技術普及バリア，家庭部門，アンケート調查，市場調査

\section{1. はじめに}

地球温暖化や環境問題が深刻化している中で, $\mathrm{CO}_{2}$ をはじめとした 温室効果ガスの排出が少ない「低炭素社会」を形成することが求め られている ${ }^{1)}$ 。COP3 (1997 年) 以降，政府は，地球温暖化対策に関す る基本方針(1999 年), 地球温暖化対策推進大綱 (1998 年, 2002 年), 京都議定書目標達成計画 (2005 年)を定めるなど, 地球温暖化対策の あり方を検討してきた。

しかし対策分野の中でも, 家庭部門は $\mathrm{CO}_{2}$ 排出量が増加傾向にあ $り^{2}$, 注 1$)$, 省エネ技術の普及阻害要因も多く残されており, 目標(理 想) と現実のギャップが依然大きいと考えられる。特に, 給湯用のエ ネルギー消費は家庭部門の約 3 割 ${ }^{3)}$ を占めており, 重要な省エネ対 策分野である。

家庭部門の省エネ型給湯器注 ${ }^{2)}$ は, 2000 年にガス式潜熱回収型給 湯器 (通称エコジョーズ), 2001 年に $\mathrm{CO}_{2}$ 冷媒ヒートポンプ式給湯機 (通称エコキュート, 電気式) が上市されてから, およそ 10 年を迎え る。しかし，本格的な普及には至っておらず，未だ従来型給湯器の 市場シェアも大きい。このような状況の中で, 給湯に関する既往調
查・研究として給湯用のエネルギー消費調查 ${ }^{4)}$ ） や給湯器の効率向 上 ${ }^{8) ~ 10)}$ に関する分析は多数行われているものの, 省エネ型給湯器の 保有実態とその阻害要因(バリア)については十分に明らかにされて いない。

省エネルギー技術の普及バリアの例としては，十分な資金調達力 がない，リスク回避的になり投資を躊躇する，物理的制約や業界構 造の影響などにより選択肢がロックインされる，消費実態や省エネ 効果に関する情報が不足している，時間や気持ちの余裕がない，関 係者間で省エネの利害が一致しない，といった問題が挙げられる ${ }^{11)}$ 〜14)。しかし, 同じ家庭部門であっても技術によってバリアの構造 は異なり,それに応じて講じるべき政策も異なることが予想される。 暖房機器の事例分析 ${ }^{15)}$ でも議論されている通り，重要なバリアを同 定し，それを乗り越えるための方策を講じていく必要がある。

そこで本研究では, 家庭部門の給湯器市場における省エネ技術普 及方策の議論に資することを目的として，消費者を対象としたイン ターネット・アンケート調查を行い, 給湯器の導入・設置実態把握 やその背景要因を分析する。また，分析に基づいて想定される主な

\footnotetext{
* 電力中央研究所社会経済研究所 協力研究員 $\cdot$ 工博

** 電力中央研究所社会経済研究所 主任研究員 ·工修

*** 東京大学生産技術研究所エネルギー工学連携研究センター 准教授・工博

Collaborating Researcher, Socio-economic Research Center, Central Research Institute of Electric Power Industry, Dr. Eng.

Researcher, Socio-economic Research Center, Central Research Institute of Electric Power Industry, M. Eng.

Assoc. Prof., Institute of Industrial Science, Collaborative Research Center for Energy

Engineering, The University of Tokyo, Dr. Eng.
} 
バリアを抽出する。本論文の構成は，以下の通りである。

まず，2 章では消費者アンケート調査の実施方法と回答者の概要 を述べ, 3 章と 4 章で調査結果を分析する。3 章では, 給湯器の保有・ 導入実態の全体像を紹介し，4 章では，市場セグメント別に掘り下 げて, 給湯器市場の動向と背景要因を分析する。最後に 5 章でまと めを述べる。

なお，本稿での「省エネ型給湯器」はガス式潜熱回収型給湯器， $\mathrm{CO}_{2}$ 冷媒ヒートポンプ式電気給湯機, 家庭用コージェネレーションと した。

\section{2.アンケート実施概要}

アンケート調查は, 2009 年 11 月にインターネットにより行った （表 1)。回収目標は 5,000 サンプルとし, 年齢 20～60 歳代の成人男 女で, 給湯器の設置・交換に直接かかわる可能性が高い「世帯主」 と「世帯主の配偶者」を対象とした。また，全国を９地域に分割注 3) して各地域 500 サンプルずつ(関東は 1,000) となるよう回収目標 を設定した。さらに，単身世帯と 2 人以上世帯，戸建と集合住宅の 比率が実態と乘離することがないよう, 統計 (平成 15 年住宅・土地 統計調査)をベースに依頼メール配布数を割り付けた。矛盾回答など を除いた後の有効サンプル数注 ${ }^{4)}$ は 4, 241 である。本報告で示す分析 結果は, 統計ベースで地域構成比を補正した後の数值である。集計 結果を解釈する際には, 次の二点について留意されたい。一点目は, 回答者が給湯器の設置・交換に主体的に関与したかどうかは, 正確 には特定できていない点である。この点については,「世帯主」と「世 帯主の配偶者」に限定することで，できる限り実態に近いデータを 取得することした。二点目は, インターネット調查特有のバイアス がかかる可能性がある点である。本多(2005) ${ }^{16)}$ によれば，インター ネット調査では, 回答者属性については高学歴, 専門・技術職が多 く, 回答者の意識については, 不満や不安感などが強く表れる傾向 がある。

表 1 アンケート調查の実施要領

\begin{tabular}{|c|c|}
\hline & アンケート調査の実施概要 \\
\hline 実施期間 & 2009年11月3日〜 6日 \\
\hline 調査対象 & 全国 (沖縄県を除く) の20歳〜69歳の方 \\
\hline 調査方法 & インターネット(ウェブ)による調査 \\
\hline サンプル & 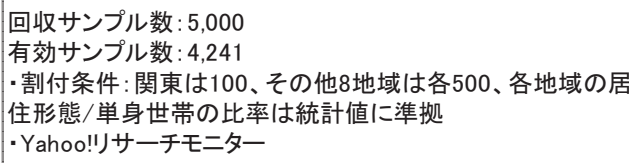 \\
\hline 調査項目の概要 & $\begin{array}{l}\text { 居住形態、世帯属性、給湯器の利用状況や保有に当たつた } \\
\text { 経緯など(予備調査: 約7問、本調査: 約 } 100 \text { 問) }\end{array}$ \\
\hline 所要時間 & $\begin{array}{l}\text { 予備調査: } 5 \text { 分程度 (世帯属性や居住形態など) } \\
\text { 本調査 }: 40 \text { 分程度 (給湯器の購入過程、利用実態など) }\end{array}$ \\
\hline
\end{tabular}

アンケート調査の主な質問内容は図 1 の通りである。まず，予備 調査で世帯属性や居住形態などをたずねたうえ, 続く本調査で給湯 器の設置年数, 住まいに関する情報, 給湯器の設置過程・印象など について詳しくたずねた ${ }^{17), 18)}$

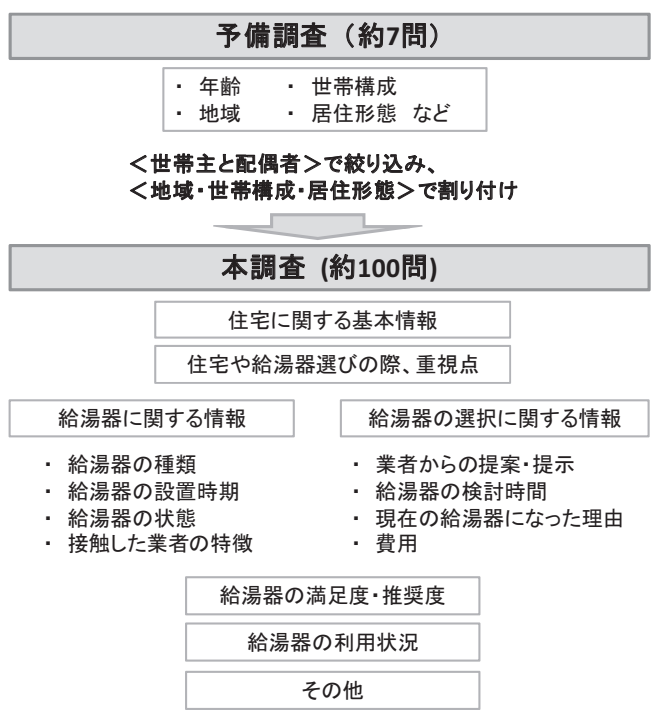

図 1 アンケートの主な内容

\section{3. 給湯器の保有 - 導入実態の全体像}

\section{3．1，アンケート回答者の属性}

主な世帯属性を図 2 に示す。世帯主が $76 \%$, 男性が $68 \%$ を占めて いる。年代別には，20～30 代が約 2 割，40 代が約 2 割，50～60 代 が約 6 割となっている。平均世帯人数は 2.66 人注 5$)$ であり, 統計值 (2. 55 人; 平成 15 年家計調査) より若干大きい。

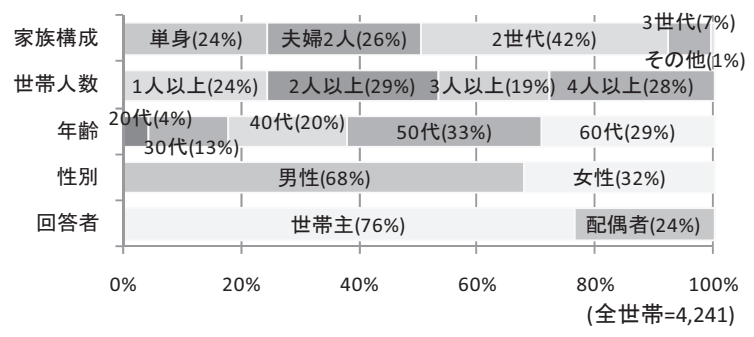

図 2 主な世帯属性

住宅の建て方・所有関係を図 3 に示す。戸建住宅の比率は $60 \%$ で あり統計值 (60\% ; 平成 15 年住宅・土地統計調查) に近いが，持家の 比率は $70 \%$ と, 統計值 (61\%; 平成 15 年住宅・土地統計調查)よりや や高めである。

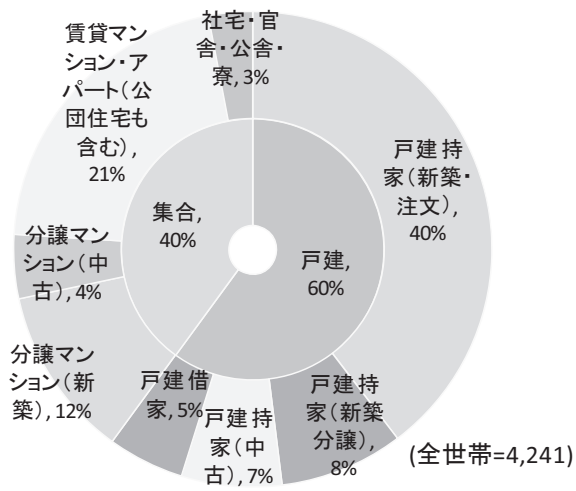

図 3 住宅の建て方・所有関係 


\section{2. 給湯器保有状況と満足度}

現在保有している給湯器の台数は, 約 9 割の世帯で 1 台であった。 また, 約 1 割の世帯では 2 台以上を保有しており，社宅・寮など $1 \%$ の世帯では個別の給湯器を持っていなかった (図 4)。複数の給湯器 を保有している理由を複数回答でたずねたところ，「風呂用と台所 用」に別々の給湯器が置かれている場合が約 6 割と多く, また, 「1 階と 2 階に別の給湯器がある」場合も約 2 割であった (図 5)。

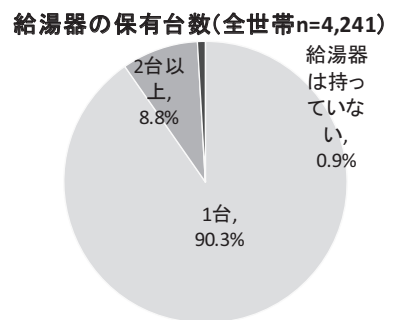

「Q. 現在のお住まいに、給湯器が何台ありますか。」

図 4 給湯器の保有台数

\section{2台以上保有している理由 $(n=384)$}

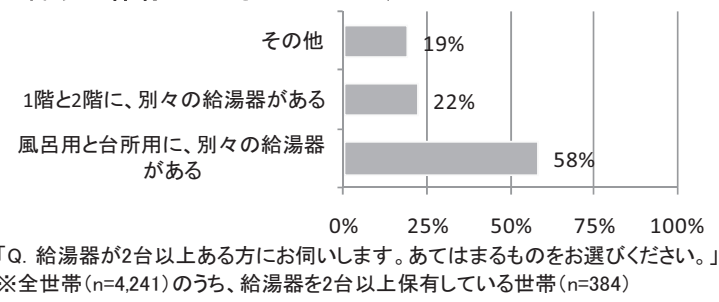

図 5 給湯器の複数台保有(複数回答)

このように，世帯によっては複数の給湯器を保有しており，使用 目的や給湯能力も異なる可能性がある。そこでアンケート調查にお いては質問内容を明確にするため, 2 台以上の給湯器を保有してい る世帯については，風呂の給湯に使われる主な給湯器について回答 するよう依頼した。以降における「給湯器」は，これを指す。

保有されている給湯器の種類を図 6 に示す。最も多いのはガス (都 市ガス・プロパンガス)をエネルギー源とした給湯器で，従来型が $66 \%$ ，省エネ型が $4 \%$, 合計で $70 \%$ ある。灯油を用いた給湯器は従 来型が $13 \%$ あり，省エネ型はわずかである。電気給湯器は従来型 で $8 \%$ ，省エネ型で $6 \%$ ，合計 $14 \%$ である。全体では，給湯器ストック の約 1 割が，省エネ型となっている。

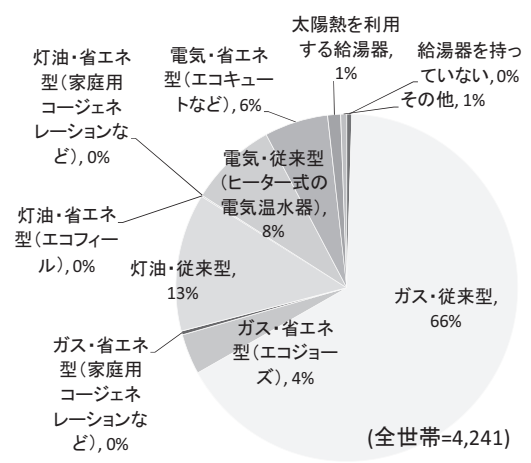

「Q.あなたの家で「お風呂などの給湯に使われる、主な給湯器】のタイプと してあてはまるものをお選びください。

図 6 保有している給湯器の種類
保有している給湯器について, 他人への推奨度を尋ねた (図 7)。 省エネ型給湯器を保有している世帯は推奨度が高めであり, 特に電 気式の省エネ型を保有している世帯では,「既に薦めた, 是非薦めた い」が $22 \%$ ，「どちらかというと薦めたい」が $69 \%$ ，他人への推奨 度が高めである。

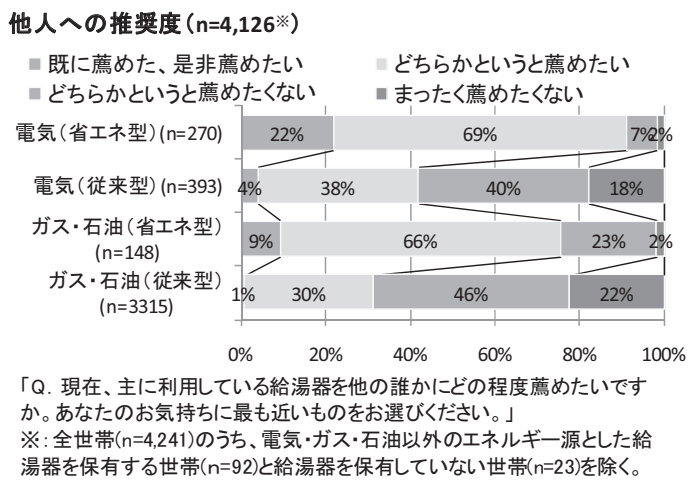

図 7 利用中の給湯器の推奨度

住まい選びの際，住宅の様々な性能についてどの程度重視してい たのかを尋㸚た（図 8)。ここでの質問項目は，国土交通省の住宅性 能表示制度で対象となっている 10 項目に, 給湯器の省エネ性能を追 加したものである。

重視度が高めであるのは,「空の面積と位置」,「地震・災害に強い 構造」,「床や壁の防音性」,「火災時の安全性」などである。「冷暖房 省エネのための省エネ性能」も比較的高いが, 「給湯器の省エネ性能」 についてはそれほど重視されていない。「水・ガス配管の維持管理・ 更新のしや寸さ」への関心も低く，水回りの裏方設備については， 住宅選びの際には関心が後回しになりがちな可能性がある。

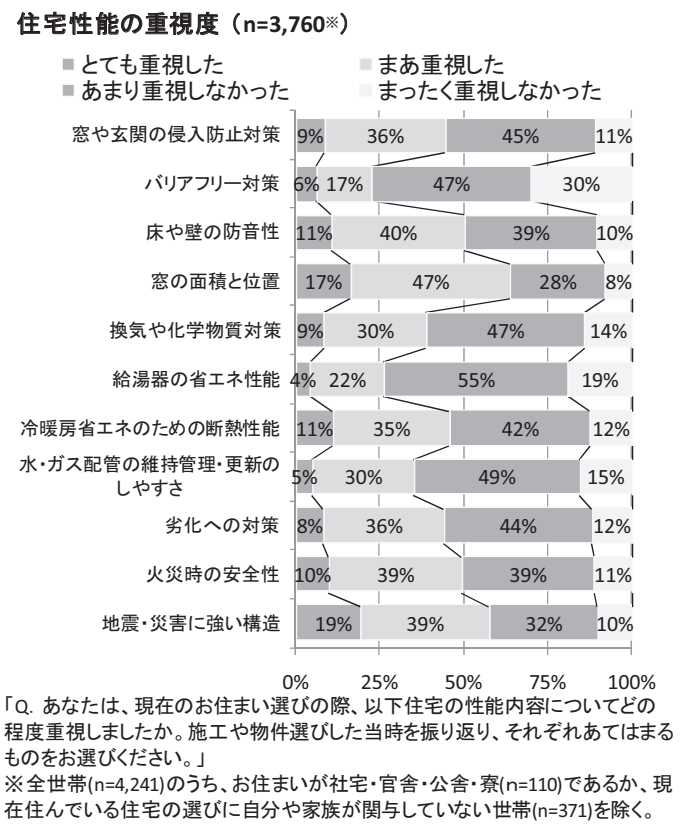

図 8 住宅性能の重視度

以上でみたように, 省エネ型給湯器の利用経験がある消費者は他 人への推奨度が高くなり，その後も省エネ性能への意識が高まる可 
能性が示唆されるが, 利用経験のない消費者は, 住まいを選ぶ際に 給湯器の省エネ性能のことをそれほど重視しない場合が多い。

\section{4. 給湯器市場別の動向と背景要因}

本章では，効果的な省エネ型給湯器の普及方策を検討するため, 設置経緯の違いを踏まえた上で, 省エネ型給湯器の採用率を左右す る背景要因への理解を深める。

文献 19) 211, 注 6) によれば, 給湯器市場は約 450 万台/年で推移して いる。給湯器の設置・交換事情は，新築住宅一の新規設置と，既築 住宅でのリプレースによって, また, 住宅形態が戸建住宅と集合住 宅であるかによっても異なると考えられる。そこで本章では,「新 築・戸建住宅」「新築・集合住宅」「既築・戸建住宅」「既築・集合住 宅」向けの 4 つの市場セグメントにわけて, 順に分析を行う。給湯 器市場別の分析対象のサンプル抽出方法を図 9 に示す。

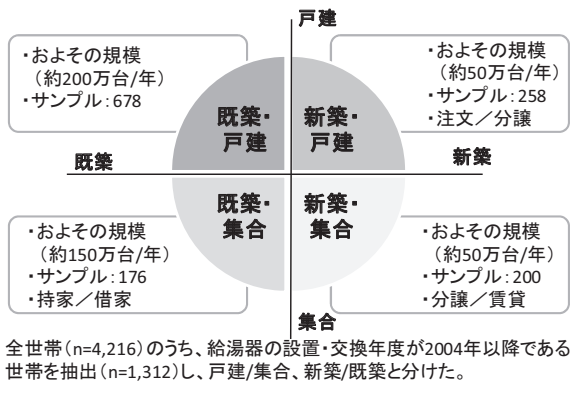

図 9 給湯器市場における分析対象サンプル

各年で集計すると十分なデータ数が確保できないため，2001〜 2003 年, 2004 2006 年, 2007〜2009 年の 3 年ごとに設置期間を区 切って集計した。また, 省エネ型給湯器の市場投入後の傾向を分析 するという趣旨に沿って,アンケートで取得した回答データのうち, 設置時期が 2004 年以降の世帯に限定して集計することとした。

\section{1. 新築・戸建住宅向け}

フローでみた省エネ型給湯器の比率を図 10 に示す。新築戸建住宅 を, 注文と分譲にわけて比較しており, 図中にも示寸通り, 分譲住 宅のサンプル数が少なめである点に留意されたい。

\section{省エネ型給湯器の比率 (新築·戸建)}

（集計サンプル数は設置時期順に※1:123,133,89、

※2:31,21,15、※3:154,154,104。比率は地域補正済み）

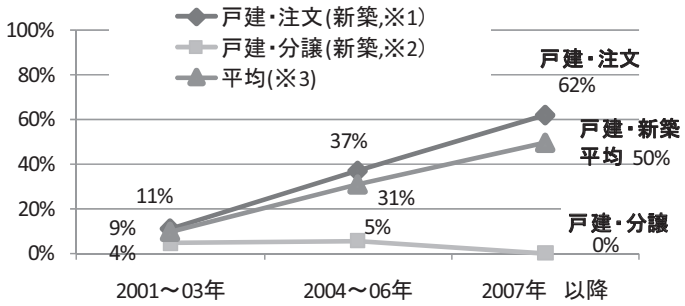

2004年度以降に新築し、新築の際に導入した給湯器をそのまま利用している世帯 $(n=258)$ に加え、参考値として新築時期が2001 03年である世帯 $(n=154)$ を示す。

図 10 省エネ型給湯器の採用率の推移 (新築・戸建)
約 6 割まで上昇しているが，分譲住宅では 1 割に満たない。

注文／分譲住宅の市場の違いを掘り下げるため, まずは, 施工会 社による差を確認しておく。図 11 は, 設置時期が 2004 年以降のデ 一夕を抽出し, 大手メーカー注7), 工務店他の二つに分けて示す。注 文住宅に着目すると，大手メーカーの方が工務店よりも省エネ型給 湯器の比率が若干高めであるものの，大きな違いがみられない。同 じ工務店で比較すると，注文住宅と分譲住宅では大きな差が見られ る。これらより, 新築戸建住宅の給湯器市場を特徵づけるのは, 施 工会社の違いよりも，注文住宅であるか分譲住宅であるかのほうが 影響するものと推測される。

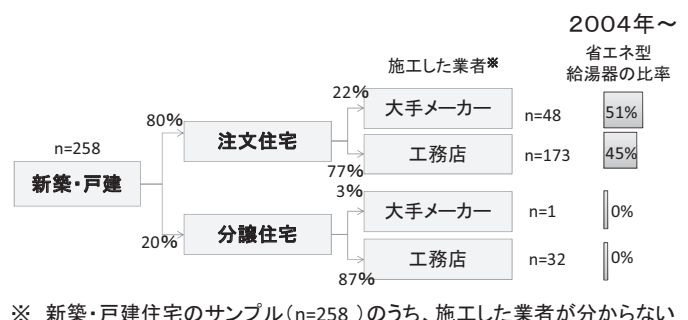
世帯(「忘れてしまった」「

図 11 施工会社による給湯器の比率 (新築・戸建)

次に, 注文・分譲住宅それぞれについて, 従来型給湯器を利用し ている世帯において, 設置されている給湯器が省エネ型ではない理 由を示す(図 12)。注文住宅では,「設置価格が高かった」の他に，「こ だわらなかった」,「選択肢が限られていた」の理由が上位に挙げら れた。分譲の場合は，「選択肢が限られていた」，「検討する時間や気 持ちの余裕がなかった」が多かった。注文住宅の設置費用について は, 住宅全体の費用から給湯器の内訳を特定できないことも多く, データ分析のための十分な回答数が得られなかった。対象サンプル は異なるが，設置費用は 4.3 節 (既築・戸建住宅向け)の図 23 で扱っ ているので，参考にされたい。

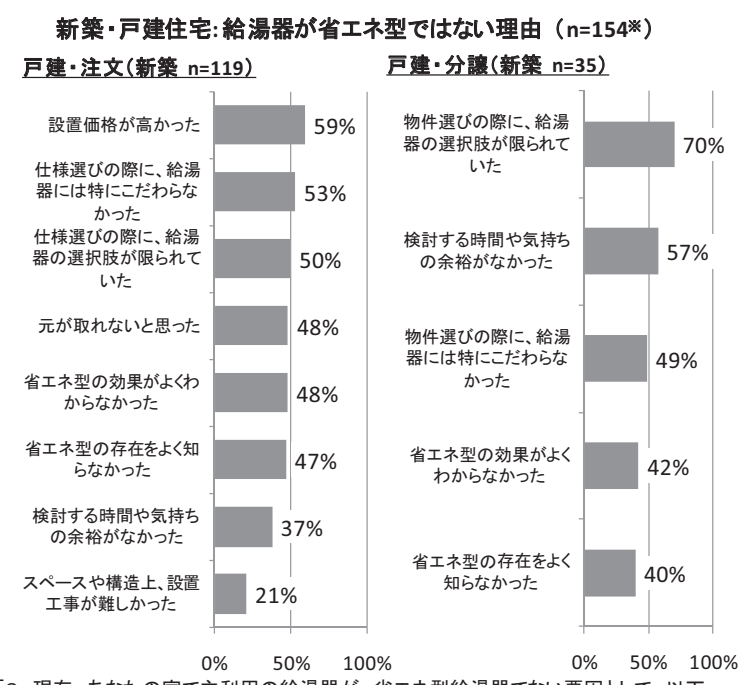

「Q. 現在、あなたの家で主利用の給湯器が、省エネ型給湯器でない要因として、以下 の内容はどの程度影響していると思いますか。それぞれあてはまるものを、1つずつお 選びください。」

「とても影響した、まあ影響した、あまり影響しなかった、まったく影響しなかった」の4段 階評価のうち、「とても影響した、まあ影響した」の割合を示す。

※2004年度以降に新築し、新築の際に導入した給湯器をそのまま利用している世帯 $(\mathrm{n}=258)$ のうち、従来型給湯器を採用している世帯 $(n=154)$ に尋ねた。

図 12 従来型給湯器を導入・設置した理由 
図 12 で両者に共通する大きな理由は「選択肢が限られていた」 である。そこでこの点を掘り下げるため, 居住者が給湯器選択に関 与寸る機会が多いであろう注文住宅について, 実際に業者から提 案・提示されたエネルギー源と給湯器の種類を図 13 に示す。注文住 宅であっても, 消費者側から別の給湯器を選ぶケースは 1 割に満た ず，実質的には，提案・提示されたものが導入されることが多い。

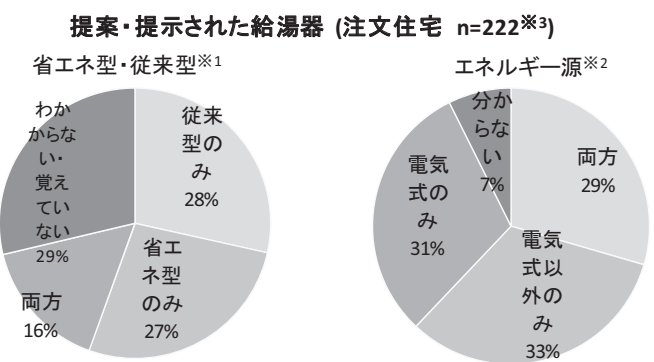

※1: 給湯器のタイプについて(左)「Q. 実際に給湯器を設置·交換した業者は、どのタイ プの給湯器を提案·提示してきましたか。あてはまるものを1つだけお選びください。」 ※2: エネルギ一源について(右)「Q. 実際に給湯器を設置·交換した業者は、どの給湯 器を提案·提示してきましたか。それぞれ、あてはまるものを1つずつお選びください。」 $※ 3: 2004$ 年度以降に新築し、新築の際に導入した給湯器をそのまま利用している世帯 $(\mathrm{n}=258)$ のうち、住宅の建て方が注文住宅である世帯 $(\mathrm{n}=222)$ に尋ねた。

図 13 提案・提示された給湯器を実際に導入する割合

勿論, 業者が提案・提示した給湯器を消費者がそのまま選択する とは限らないし，初期費用の高さなどから従来型が選ばれることも あるが，特にこだわりがない消費者の場合業者次第で設置される給 湯器が左右されがちである。そこで, 分譲住宅購入者が, 住宅購入 時に重視するポイントを尋ねた結果を示す(図 14)。住宅全般につい ては「とても重視した」と「まあ重視した」の合計割合が高いため, ここでは「とても重視した」の割合のみ表示している。

\section{戸建・分讓(新築·従来型給湯器保有世帯 $n=35 \%$ )}

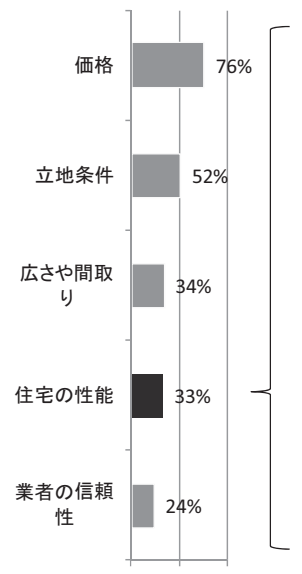

$0 \% \quad 50 \% \quad 100 \%$

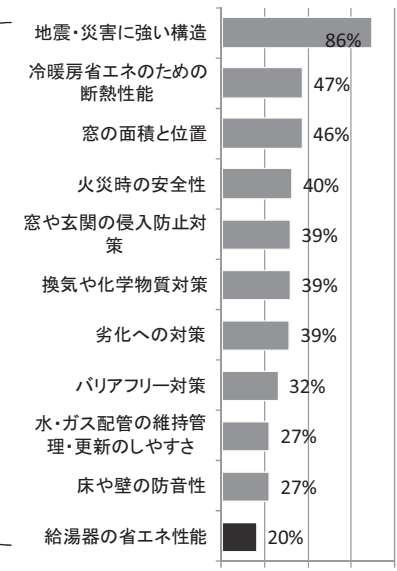

$0 \% \quad 25 \% \quad 50 \% \quad 75 \% 100 \%$
1. 左:「Q. あなたは、お住まいの施工会社・物件選びの際に、以下の内容をどの程度 重視されましたか。それぞれあてはまるものをお選びください。」

2. 右:「Q. あなたは、現在のお住まい選びの際、以下住宅の性能内容についてどの程 度重視しましたか。施工や物件選びした当時を振り返り、それぞれあてはまるものをお 選びください。」

3、「とても重視した」「ああ重視した」「あまり重視しなかったっ「まったく重視しなかった」 の4段階の選択肢うち、住宅全般については「とても重視した」の割合を、住宅性能につ いては「とても重視した」なああ重視した」の割合を示す。

※2004年度以降に新築し、新築の際に導入した給湯器をそのまま利用している世帯 $(n=258)$ のうち、住宅の建て方が分袞住宅であり、従来型給湯器を保有している世帯 $(n=35)$ に尋ねた。

図 14 戸建・分譲住宅購入時の重視点

（左：住宅全般，右：住宅の各性能）
住宅全体 (同図左)で最も重視されているのは住宅価格であり，立 地条件がこれに続く。住宅の性能を「とても重視した」購入者は, 約 3 割であった。次に, 住宅の性能について尋ねたところ(同図右), 給湯器の省エネ性能はあまり重視されていない。このように, 分譲 住宅購入者側では給湯器性能の優先順位が高くないのが現状で，マ 一ケティングの観点からも，施工会社側が積極的に省エネ型給湯器 を選ぶ動機が不足している可能性が推察される。

\section{2. 新築・集合住宅向け}

集合分譲住宅の場合，2007 年以降の省エネ型給湯器の比率は約 5 割に上昇しており，1割に満たない賃貸とは対照的である(図 15)。

\section{省エネ型給湯器の比率 (新築·集合)}

（集計サンプル数は設置時期順に※1:58,44,30、

※2:57,82,44、※3:115,126,74。比率は地域補正済み）

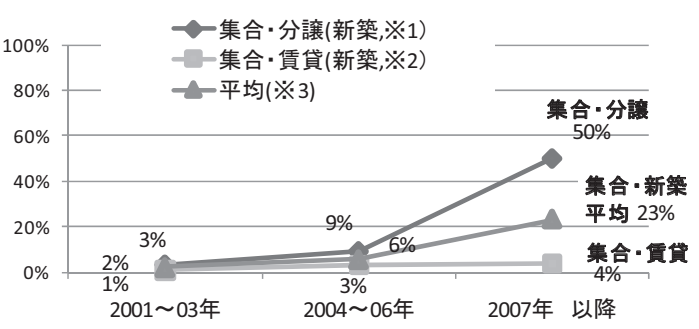

2004年度以降に新築し、新築の際に導入した給湯器をそのまま利用している世帯 $(n=200)$ に加え、参考値として新築時期が2001 03年である世帯 $(n=115)$ を示す。

図 15 省エネ型給湯器の採用率の推移(新築・集合)

分譲と賃貸の省エネ進展度の違いを探るために，物件選びの際に 重視した点を比較する (図 16)。共通する特徵としては, 価格や立地, 間取りなどが上位にきて，住宅性能への重視度が低い点が挙げられ る。賃貸住宅の方が全般に重視度が低い。

新築-集合住宅: 物件選びの際の重視度 ( $n=200 \%)$

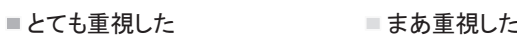
ロあまり重視しなかった 注ったく重視しなかった

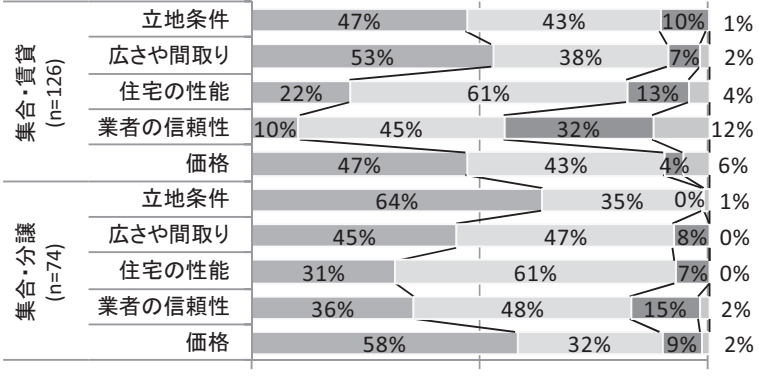

$0 \%$ $50 \%$ $100 \%$

「Q. あなたは、お住まいの施工会社·物件選びの際に、以下の内容をどの程 度重視されましたか。それぞれあてはまるものをお選びください。」 ※2004年度以降に新築し、新築の際に導入した給湯器をそのまま利用して いる世帯 $(n=200)$ に尋ねた。

図 16 新築・集合住宅における物件選びの重視点

このように住宅性能に対する希望は後回しになりがちなため,デ ベロッパーや住宅メーカーが採用機器を決定する際にも優先順位が 下がる可能性がある。さらに，光熱費節約のメリットが享受できな い建設側からすると，コスト増につながる省エネ機器を選ぶ動機に 
欠け，低効率で費用のかからない機器が選ばれてしまいがちである

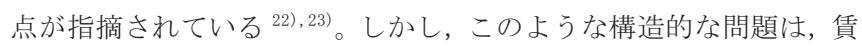
貸住宅における省エネ型の採用率の低さは説明できるものの, 分譲 住宅における比較的高い採用率については説明しきれない。特に,

同じ分譲住宅であっても, 新築・戸建住宅よりも新築・集合住宅の 方が省エネ給湯器の採用率が高い点は注目に值する。

本アンケート調查では，この点を裏付けるデータを取得していな いため，仮説にはなるが，分譲用の集合住宅における競争環境の影 響も想定される。先の図 16 では, 分譲住宅を選ぶ際に賃貸に比べて 「業者の信頼性」を重視する比率が高かった。また, 集合住宅での住 宅設備の採用実態に関する調査 ${ }^{24)}$ においては, 給湯器以外でも分譲 用集合住宅のほうが賃貸住宅より良い設備を導入する割合が高いこ とが指摘されている。一般に分譲用集合住宅デベロッパーは賃貸住 宅デベロッパーよりも大手であり, 総供給戸数が多いと思われるた め，仕入れにおける購買力を発揮でき，省エネ型とすることによる 費用負担を抑えられる可能性もある。同じ分譫住宅でも戸建住宅と 集合住宅で傾向が異なる理由については，今後明らかにしていく必 要がある。

\section{3、既築·戸建住宅向け}

2007 年以降で, 既築戸建住宅で設置・交換される給湯器の約半数 は省エネ型であり，この省エネ化の傾向は新築戸建住宅における採 用の推移と似ている(図 17)。なお, 集合賃貸住宅の場合は新築時か ら賃貸目的に位置付けられた住宅も多く含まれるため，それらを明 確に区別して分析する必要があると考えられるが，戸建賃貸住宅の 場合は当初持家だった住宅が賃貸されるケースも多めになると推測 されることから，本節の戸建住宅では持家と賃貸を区分せず分析す ることにした。

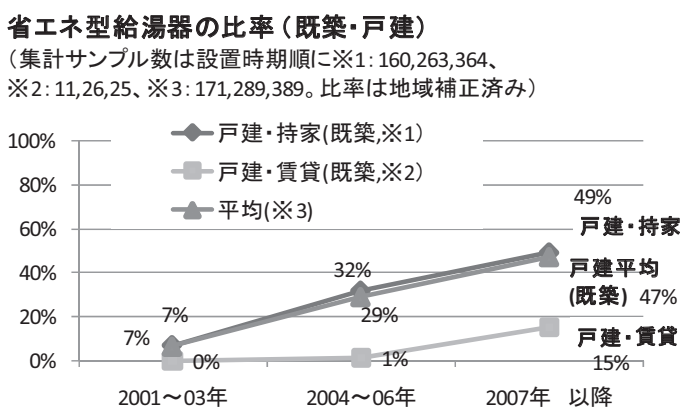

既築·戸建で2004年度以降、給湯器を交換した経験のある世帯 $(n=678)$ に加え、参考 值として新築時期が2001 03年である世帯 $(n=171)$ を示す。

図 17 省エネ型給湯器の採用率の推移(既築・戸建)

はじめに, 従来型給湯器のサンプルに限定して, 省エネ型給湯器 を採用しなかった点について，消費者側が感じている理由を確認し ておく。図 18 に示すように, 省エネ型ではない理由として「設置価 額が高かった」の割合が一番大きく,「選択肢が限られていた」,「特 にこだわらなかった」も多い。ただし，全般的には他の市場セグメ ントと比べると回答がばらける傾向にある。既築では「スペースや 構造上，設置工事が難しい」場合も予想されたが，ここでの消費者 側の認識を見ると，最も該当率が低かった。ただし，数值に表れる
のは消費者側が明確にこの問題を認識した場合の割合であり，業者 側であらかじめスペースや構造を踏まえて省エネ型給湯器を提案か ら外している可能性もある。この場合は，「選択肢が限られていた」 などと重複するところもあるだろう。

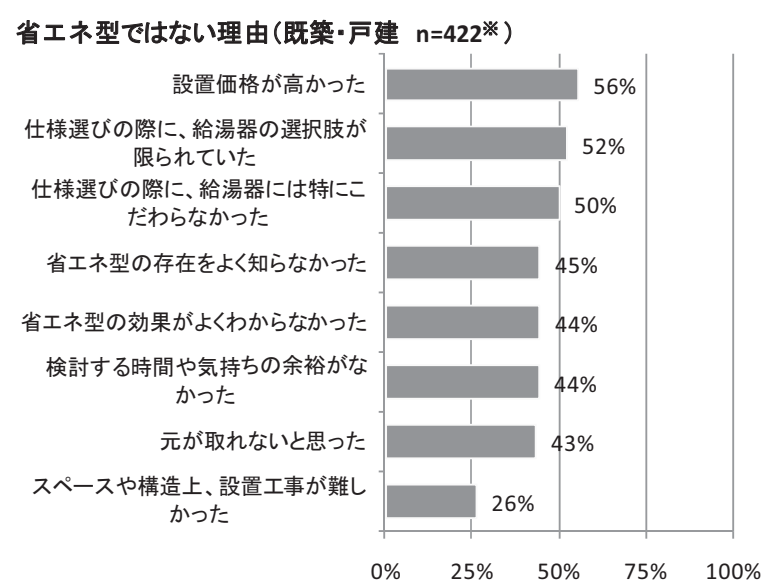

1.「Q. 現在、あなたの家で主利用の給湯器が、省エネ型給湯器でない要因として、以 下の内容はどの程度影響していると思いますか。それぞれあてはまるものを、1つずつ お選びください。」

2.「とても影響した、まあ影響した、あまり影響しなかった、まったく影響しなかった」の4 段階評価のうち、「とても影響した、まあ影響した」の割合を示す。

※既築·戸建で2004年度以降、給湯器を交換した経験のある世帯 $(n=678)$ のうち、従 来型給湯器を保有している世帯 $(n=422)$ に尋ねた。

図 18 設置・交換した給湯器が省エネ型でない理由

次に, 給湯器設置・交換の経緯を図 19 に示す。まず，給湯器の状 態で見ると，設置・交換する前に給湯器に何らかの不具合があった ケース (以下, 「不具合後」) が約 6 割で, 不具合が出る前に設置・交 換に至ったケース (以下,「不具合前」) 注8) が約 4 割であった。また, 設置・交換した業者の性格によって，その住宅の建設業者や当時利 用中だった給湯器に関係する業者（以下，「縁あり」) と，それ以外の 業者(以下，「縁なし」） ${ }^{\text {注 }}{ }^{9)}$ に二分化したところ，約半分ずつであっ た。

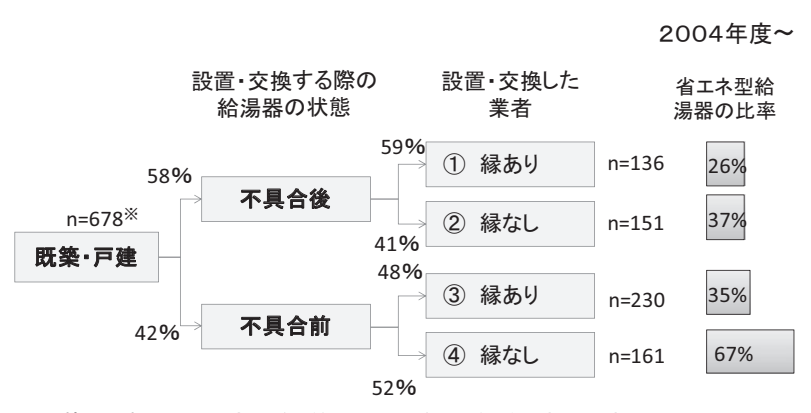

※既築·戸建で2004年度以降、給湯器を交換した経験のある世帯 $(n=678)$ に尋ねた。

図 19 給湯器の設置・交換経緯

経緯による違いをより詳しく考察するために，まず，業者との接 触方法について比較する (図 20)。ここでは, 最終的に自分・業者ど ちらが連絡を入れたかを尋ねた。例えばチラシをみて連絡を入れた 場合も「自分から」に分類されるので，正確な経緯まではわからな いが，ある程度経緯の違いを見ることはできよう。全体的には「自 分から」連絡を入れた割合が高いが, 縁なし, 特に不具合前の場合, 
最後に省エネ型ではない理由として一番多かった「設置価格が高 かった」について, エネルギー源や給湯器のタイプ別の給湯器の設 置諸経費を図 23 に示す。設置諸経費は本体価額と工事などの諸経費 の合計から補助金を引いた事実上支払った総額を指す。またここで は，給湯器の設置・交換費用を負担し，およその額も分かっている と回答したサンプルに限定して集計している。平均值をみると，電 気式については省エネ型が約 80 万円, 従来型が約 40 万円であり, およそ 40 万円の差であった。また, ガス・石油式については省エネ 型で約 27 万円，従来型は約 20 万円と，数万円の差であった。

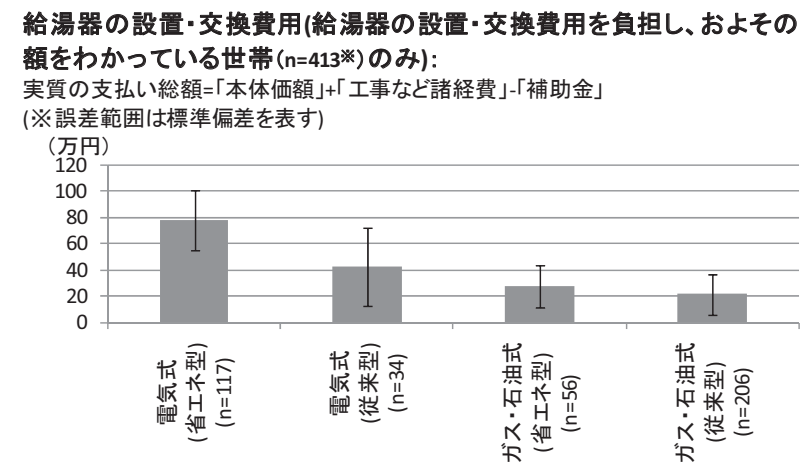

「Q. あなたの家で主に利用している給湯器の設置·交換費用を、実質の支払い総額に てお選びください。※なお、実質支払い総額 $=「$ 本体価格」+「工事など諸経費」-「補助 金」。ローンやリースの場合は、およその総額でお答えください。」

※既築·戸建で2004年度以降、給湯器を交換した経験のある世帯 $(n=678)$ のうち、給湯 器の設置·交換費用を負担し、およその額を分かっている世帯 $(n=413)$ に尋ねた。

図 23 給湯器の設置・交換費用

\section{4. 既築・集合住宅向け}

このセグメントでは，いずれの比率も 1 割に満たない(図 24)。同 じ持家でも前節で夕た既築・戸建住宅の比率と比べると低い。

しましたか。」

※既築・戸建で2004年度以降、給湯器を交換した経験のある世帯 $(n=678)$ の うち、住宅の所有関係が持家である世帯 $(n=627)$ に尋ねた。

図 21 設置・交換する際に接触した業者の数

次は, 業者から提案・提示された給湯器を比較する (図 22)。この うち, (1)不具合後・縁ありのケースでは「わからない・覚えていな い」を除くと, 約半分以上のケースで「従来型のみ」が提案・提示 されているケースが多い。これに対して，不具合前・縁なし(4)の 場合ではそのようなケースは約 2 割程度しかなく, むしろ省エネ型 給湯器が推奨されているケースが約 6 割を占める。

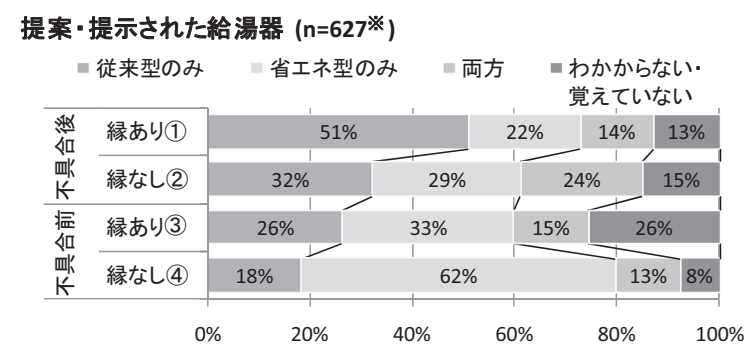

「Q. 実際に給湯器を設置·交換した業者は、どのタイプの給湯器を提案·提示 してきましたか。あてはまるものを1つだけお選びください。」

※既築·戸建で2004年度以降、給湯器を交換した経験のある世帯 $(n=678)$ の

うち、住宅の所有関係が持家である世帯 $(n=627)$ に尋ねた。

図 22 提案・提示された給湯器
省エネ型給湯器の比率 (既築·集合)

（集計サンプル数は設置時期順に※1: $15,42,37 、 ※ 2: 16,36,61$ 、 ※3:31,78,98。比率は地域補正済み）

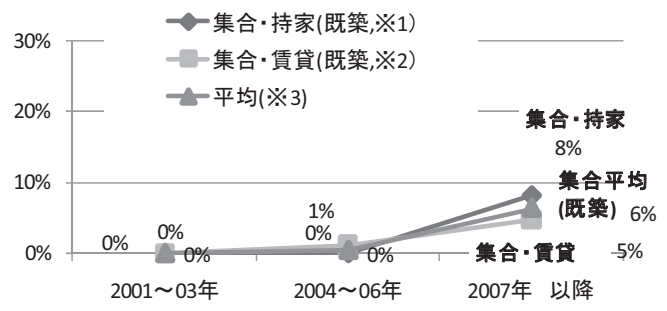

既築·集合で2004年度以降、給湯器を交換した経験のある世帯 $(n=176)$ に加え、 参考值として新築時期が2001 03年である世帯 $(n=31)$ を示す。

図 24 省エネ型給湯器の比率(既築・集合)

既築集合住宅において, 最も多かった理由は,「仕様選びの際に, 給湯器の選択肢が限られていた」であった。また，集合・持家の場 合には「スペースや構造上，設置工事が難しかった」の理由が $55 \%$ の割合で上位に挙げられており，既築の戸建住宅とは違う傾向をみ せる(図 25)。耐久荷重や配管のために設置工事が難しい場合や，電 気式給湯器用電力契約容量を自由に増やせない場合などが影響し, 結果として，省エネ型への更新やエネルギー源の転換は容易でない ものと推察される。 


\section{集合·既築住宅 : 給湯器が省エネ型ではない理由 $(n=167 \%)$ 集合·持家（既築 $n=75$ ) \\ 集合·借家 (既築 $n=92$ )}

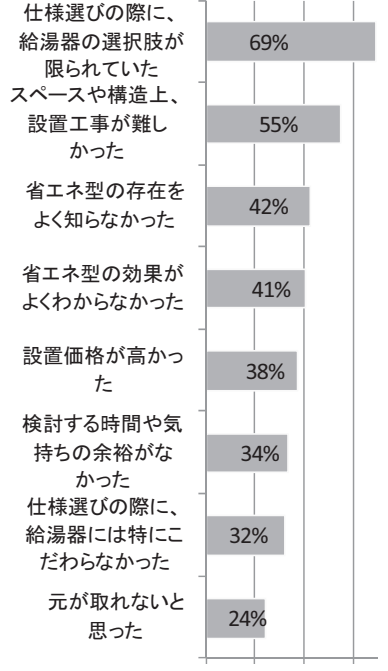

$\begin{array}{llll}0 \% & 20 \% & 40 \% & 60 \%\end{array}$

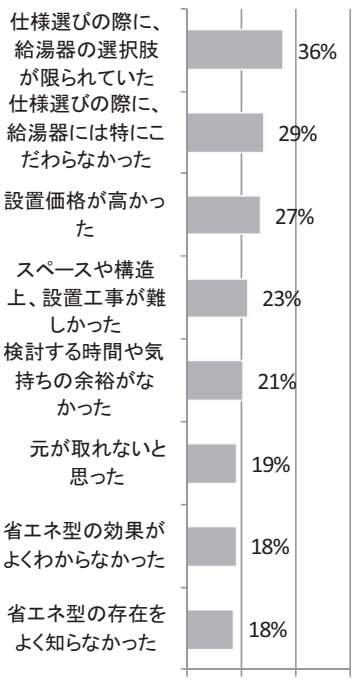

$\begin{array}{llll}0 \% \quad 20 \% & 40 \% \quad 60 \%\end{array}$
1.「口. 現在、あなたの家で主利用の給湯器が、省エネ型給湯器でない要因として、以 下の内容はどの程度影響していると思いますか。それぞれあてはまるものを、1つずつお 選びください。」

2.「とても影響した、まあ影響した、あまり影響しなかった、まったく影響しなかった」の4 段階評価のうち、「とても影響した、まあ影響した」の割合を示す。

※既築·集合で2004年度以降、給湯器を交換した経験のある世帯 $(n=176)$ のうち、従来 型給湯器を保有している世帯 $(n=167)$ に尋ねた。

図 25 設置・交換した給湯器が省エネ型ではない理由

さらに, 給湯器を設置交換する際にかかわる業者の性格をみると, 「住まいを建設している業者・または提携業者」・「同時利用していた 給湯器の業者, または提携業者」の縁のある業者を利用する割合が 高い(図 26)。この場合, 既築・戸建でも考察した通り, 現状の給湯 器のエネルギー源や給湯器のタイプが維持される傾向となる。

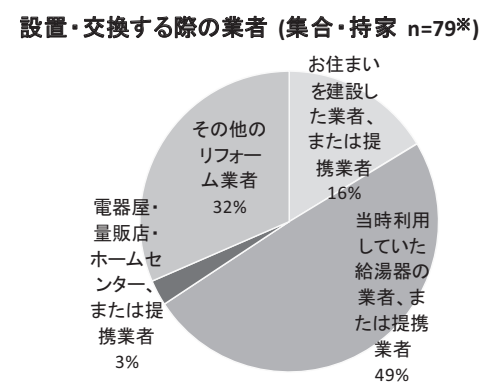

「Q. 実際に設置·交換をした業者のタイプとして、あてはまるものをお選 びください。」

※既築·集合で2004年度以降、給湯器を交換した経験のある世帯 $(n=176)$ のうち、持家である世帯 $(n=79)$ に尋ねた。

図 26 設置・交換した業者のタイプ

集合・賃貸住宅では，「選択肢が限られていた」，「特にこだわらな かった」を主な理由で挙げられている。また，図 27 で示すように， 給湯器選びの際に借り手である居住者の希望が「反映された」と回 答したのは約 2 割にとどまる。「希望する立場になかった」「特に希 望はなかった」が半数以上を,「まったく反映されなかった」「あま り反映されなかった」も約 2 割を占める。このように, 賃貸住宅の 給湯器選択は, 実質的にオーナー側の判断に委祆られている場合が 多い。

\section{借り手の希望の反映度(n=97\%)}

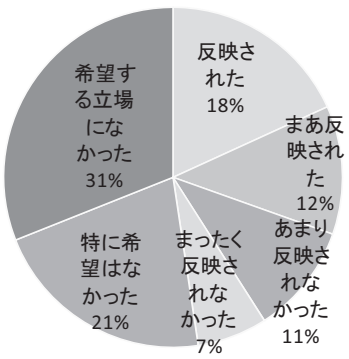

「Q. 入居後に新たに設置された給湯器のタイプは、借り手であるあ なたやご家族の希望が反映されたものでしたか。」

※既築·集合で2004年度以降、給湯器を交換した経験のある世帯 $(n=176)$ のうち、貸貸住宅である世帯 $(n=97)$ に尋ねた。

図 27 借り手の希望の反映度

\section{5。市場セグメントによる傾向の違い}

最後に, 4.1 ～ 4.4 節の分析結果を踏まえ，市場セグメントによる 傾向の違いについて考察する。まず, 図 28 に, 給湯器市場の特性を 整理する。

横軸には省エネ型給湯器の採用率を示し，右側に行くほど，採用 率は高くなる。前節まで分析で示したとおり，2007〜09 年の採用例 では，注文住宅で 6 割程度の採用率である。参考のため，既往統計 等を参考注 6 ) に推計した各セグメント別のおよその市場規模(出荷台 数）を，円の大きさで表した。市場規模が最大なのは既築・戸建住 宅向けの約 200 万台である。また，新築・戸建，新築・集合，既築・ 集合住宅については，建て方や所有形態の違いも示している。

縦軸には，給湯器選択に主に関与するアクターを示しており，上 側ほど消費者が直接的に関与し，下側ほど消費者の関与は間接的に， すなわち，実質的には住宅建設業者やリフォーム業者，賃貸住宅才 一ナーが採用決定者となる。位置関係については, アンケートから 定量的に算出したものではなく，結果から示唆される傾向を定性的 に表している。例えば既築・集合住宅の持家の場合は，本来的には 既築・戸建住宅の持家と同様に消費者に採用権があるものの，実際 には，スペースや構造上の問題などにより給湯器の選択肢がより制 約される可能性などを反映した（前掲図 18，25 の比較）。前節まで の分析でも見たように，消費者の関与度が高いほど初期費用の問題 や情報不足などの問題が普及阻害要因 (バリア)として大きくなり， 消費者以外が採用決定者になるほじ，省エネ型を採用する動機の不 足の問題が影響してくる可能性がある。

ここで，それらセグメント別に省エネ型給湯器の普及バリアにつ いて考察する。その際に，まずは普及バリアの概念を整理しておこ う。先行研究においては, 省エネルギー技術の普及バリアとして, 次のような問題が指摘されている ${ }^{14)}$

- 資金調達力やリスク：省エネ型は従来型に比べて初期費用 が高いことが多く，消費者にとってはできるだけ早めに元 をとりたいと思うので，採用をためらいがちである。

- 情報不足や限定合理性 : 消費者が省エネ型のメリットにつ いてよく知らないことや検討する時間や気持ちの余裕がな いことで，十分に吟味しないまま省エネ型ではないものを 選択してしまう可能性がある。

- 動機の分断 : 利用者と購入決定者が異なる場合, 省エネ型 を導入されにくくなる可能性がある。賃貸契約が関係する 


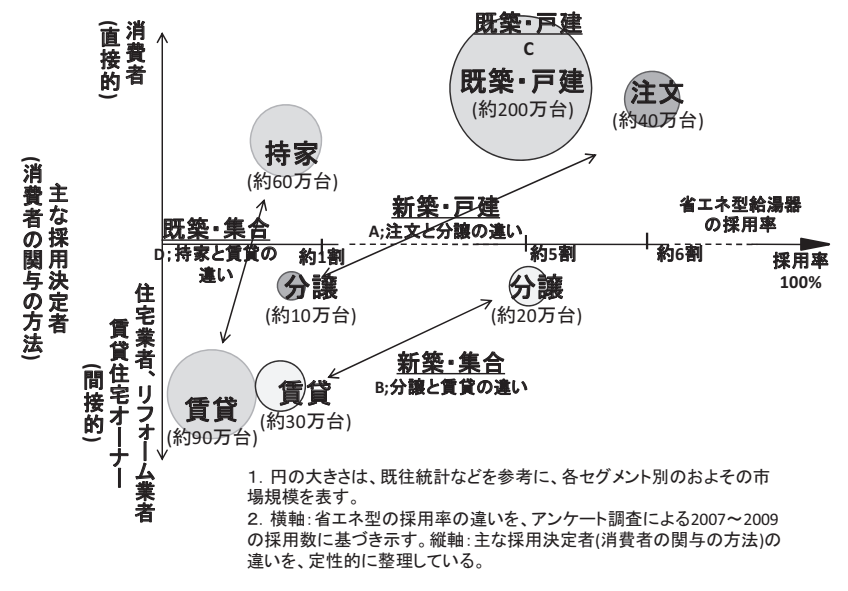

図 28 給湯器市場の特性

場合はオーナー・テナント問題とも呼ばれ，例えば，採用 権を持つアクターにとっては光熱費削減などのメリットを 享受できない場合，初期費用を抑えることが優先されがち である。

- ロックイン：設置スペースや住宅構造上の問題で, 機器の エネルギー源やタイプに対する選択肢が限られてしまう。 特に, 既築の場合は交換時に利用していた給湯器の影響を 受けや寸く，機種やエネルギー源が維持される傾向がある。 あるいは, 特定のチャネル(販売経路)に接触した時点で, 選択肢が限られてしまう。

上の概念を援用しながら，以下ではアンケート調査から各セグメ ント別に得られる示唆と，想定される普及バリアを考察する。

(1) 新築・戸建住宅向け

注文住宅の方が, 分譲住宅よりも省エネ型給湯器, 電気式給湯器 の採用率が高かった。このような住宅の売り方による違いのほうが， 大手メーカーと工務店といった施工会社の違いよりも採用率に影響 すると推測される。分譲住宅より注文住宅のほうが, 給湯器に関す る情報量も多い。しかし, 注文住宅でも初期費用の高さなどから従 来型が選ばれることもある (=資金調達力やリスクの問題)。また, 住宅選びの際には給湯器の省エネ性能へのこだわりが他の住宅性能 より相対的に低く, 業者のラインナップや情報に左右されがちであ る (=情報不足や限定合理性)。光熱費削減メリットを享受できない 建設業者が給湯器選択の役割を担う分譲住宅では, さらに採用率が
低くなる (=動機の分断)。

(2) 新築・集合住宅向け

集合分譲住宅では，省エネ型給湯器の採用率が上昇している。物 件選びの際に住宅性能の重視度は必ずしも高くなく, 給湯器につい て考える余裕はあまりなく(=情報不足や限定合理性), 光熱費削減 メリットを享受できない建設業者は省エネ型を採用寸る動機に欠け るはずだが (=動機の分断)，同じ分譫でも，戸建分譲住宅より採用 率が高い。アンケートデータからその理由は明らかでないが，仮説 としては, 分譲用の集合住宅における競争環境の影響や，仕入れ価 格の違いなどの影響などが推測される。その詳細については今後の 課題である。

賃貸住宅での採用率は依然として低い。借り手側からの省エネ性 能のニーズもそれほど高くないこともあり，オーナー側に省エネ型 を採用する十分な動機が働いていない(＝動機の分断)。

(3) 既築・戸建住宅向け

省エネ型の採用率は，不具合に伴う交換や当時利用していた給湯 器の関連業者などに依頼した場合において低めとなるが（＝ロック インの問題), 全般的には採用率が上昇している。省エネ型は初期費 用が高いという問題や (=資金調達力やリスクの問題), 業者のライ ンナップに左右されがちという課題があるが (=情報不足や限定合 理性), 他のセグメントよりは給湯器選びに消費者の意識が向きやす いことが採用率上昇の一要因と推察される。不具合が出る前にそれ まで縁のなかった業者と接触する場合においては，省エネ型の採用 率が高めである。

(4) 既築集合住宅向け

集合住宅ではスペース・構造上の問題も加わるので, 交換時に利 用していた給湯器のタイプやエネルギー源が維持される傾向にあり (=ロックインの問題), 省エネ型の採用率は低い。賃貸住宅ではさ らに, 居住者が給湯器選択に関与寸ることが難しく関心も低く, 光 熱費削減メリットを直接享受できないオーナーの選択に委衫られる ことが多い(=動機の分断)。

以上で考察した各セグメントにおける普及バリアを表 2 に整理し た。このように各セグメント別に想定される普及バリアは大きく異 なることが示唆される。

\section{5. まとめ}

本稿では, 消費者を対象とした全国約 4200 世帯へのインターネッ 卜調查を通じて, 給湯器の保有・導入実態を把握するとともに, 住

表 2 分析結果から想定される主なバリア

\begin{tabular}{|c|c|c|}
\hline & & 省エネ型給湯器の普及に向けて想定される主なバリア \\
\hline \multirow[t]{2}{*}{$\begin{array}{l}\text { 新築·戸建 } \\
\text { 住宅向け }\end{array}$} & 注文住宅 & $\begin{array}{l}\text { ·【資金調達カ•リスク】省エネ型給湯器の初期費用は高く、消費者が積極的に選ぶことができない } \\
\text { ·【情報不足·限定合理性】住宅選びの際に給湯器の省エネ性能につなて考える、業者のラインナップや情報に左右されがちである }\end{array}$ \\
\hline & 分譲住宅 & $\begin{array}{l}\text { ·【動機の分断】分譲住宅の建築業者は、費用のかかる省エネ給湯器は採用したがらない } \\
\text { ·【限定合理性】住宅選びの際に給湯器の省エネ性能について考える余裕はなく、業者のラインナップや情報に左右されがちである }\end{array}$ \\
\hline \multirow[t]{2}{*}{$\begin{array}{l}\text { 新築·集合 } \\
\text { 住宅向け }\end{array}$} & 分譲住宅 & $\begin{array}{l}\text { ·【動機の分断】分譲住宅の建築業者は、費用のかかる省エネ給湯器は採用したがらない } \\
\text { ·【情報不足·限定合理性】住宅選びの際に、器の省エネ性能について考える余裕がない }\end{array}$ \\
\hline & 賃貸住宅 & $\begin{array}{l}\text { ·【動機の分断】貨貸住宅オーナ一は、費用のかかる省エネ給湯器は採用したがらない } \\
\text { ·情報不足·限定合理性】住宅選びの際に、給湯器の省エネ性能について考える余裕がない }\end{array}$ \\
\hline $\begin{array}{l}\text { 既築·戸建 } \\
\text { 住宅向け }\end{array}$ & & $\begin{array}{l}\text { ·【資金調達カ・リスク】省エネ型給湯器の初期費用は高く、消費者が積極的に選ぶことができない } \\
\text { ·【ロツクイン】故障にともなう交換時には従前から利用していた給湯器の関係業者に接触することが多く、エネルギー源の変更は選択肢になりににくい } \\
\text { ·【情報不足·限定合理性】給湯器選びの時間や気持ちの余裕がなく、業者のラインナツブや情報に左右されがちである }\end{array}$ \\
\hline \multirow{2}{*}{$\begin{array}{l}\text { 既築·集合 } \\
\text { 住宅向け }\end{array}$} & 持家住宅 & ·【ロックイン】スペース・構造上の問題で、エネルギー源の変更は実質的に難しい \\
\hline & 賃貸住宅 & \begin{tabular}{|l} 
·【ロックイン】スペース・構造上の問題で、エネルギー源の変更は実質的に難しい \\
·【動機の分断】賃貸住宅オーナーは、費用のかかる省エネ給湯器は採用したがらない
\end{tabular} \\
\hline
\end{tabular}


宅タイプや給湯器の導入タイミングによる給湯器選択の違いやその 背景要因について分析を行った。

省エネ型給湯器の採用率は徐々に高まりつつあるものの, その実 態は市場セグメントにより異なる。省エネ型給湯器利用者の満足度 や他人への推奨度は従来型利用者より高いものの, 実態としては, 住宅選びにおける検討項目としての優先順位は必ずしも高くなく， 十分な検討時間をかけずに設置・交換されてしまう場合が多い。消 費者が直接的に関与できる市場とサブユーザーや賃貸住宅オーナー の関与が高い市場では普及バリアが異なるということは, 情報提供 や，導入補助のような経済的インセンティブ，規制的措置などの期 待される効果も異なることが示唆される。省エネ型給湯器の採用率 を上げていくためにも, 普及バリアの実態に応じて, 政策を講じて いくことが重要である。また, 設備更新時には選択肢がより限定さ れやすい(特に集合住宅)ので，新築段階から省エネ対策を実施して おくことが重要であろう。

今後は，具体的な政策のあり方について，実効性や影響も踏まえ ながら検討していく必要がある。

\section{参考文献}

1）脱温暖化 2050 プロジェクト・都市チーム (2009)：低炭素年の実現へ向け ての解析, 環境省 地球環境研究総合推進費 戦略研究開発プロジェクト (S-3)「脱温暖化 2050 プロジェクト」 , 2009.2. http://2050.nies.go.jp/report/file/1cs_japan/2050_LCS_urbanleaflet 20090208. pdf, (accessed 2010-06-02)

2) 国立環境研究所 (2010)：日本の温室効果ガス排出量データ（1990～2008 年度)確定值, 2010.4. http://www. nies. go. jp/whatsnew/2010/20100415/2 0100415. html, (accessed 2010-06-10)

3）日本エネルギー経済研究所計量分析ユニット：EDMC エネルギー・経済統 計要覧 (2009 年版), (財)省エネルギーセンター, 2009.2. http://www. iee j. or. jp/edmc/index2.html, (accessed 2010-06-10)

4）長谷川善明, 井上隆全：国規模アンケートによる住宅内エネルギー消費 の実態に関する研究 世帯特性の影響と世帯間のばらつきに関する考察 その 1 ，日本建築学会環境系論文集 第 583 号，pp. 23〜 28, 2004.9

5）外岡豊, 深澤大樹, 村橋喜満, 三浦秀一: 都道府県別 - 建て方別住宅工 ネルギー消費量と $\mathrm{CO}_{2}$ 排出実態の詳細推計, 日本建築学会環境系論文集, 第 592 号, pp. 89 96, 2005. 6

6）村上周三, 坊垣和明, 田中俊彦, 羽山広文, 吉野博, 赤林伸一, 井上隆, 飯尾昭彦，鉾井修一，尾崎明仁，石山洋平：全国の住宅 80 戸を対象とした エネルギー消費量の長期詳細調査一対象住宅の属性と用途別エネルギー消 費量，日本建築学会環境系論文集，第 603 号，pp. 93～100，2006. 5

7）前真之, 高須直子, 鍋島美奈子, 市川憲良, 飯尾昭彦, 鎌田元康 : 住宅 における給湯日消費量の季節・短期変動, 日本建築学会環境系論文集, 第 622 号, pp. $73 \sim 80,2007.12$

8）王祥武, 前真之, 岩本靜男, 鎌田元康 : 住宅用給湯システムの熱効率お よび熱損失の検討 住宅用給湯システムの効率評価法に関する研究 第 1 報，日本建築学会環境系論文集，第 580 号，pp. $61 \sim 68,2004.6$

9）柴田善朗, 村越千春, 中上英俊 : 使用条件下における $\mathrm{CO}_{2}$ 冷媒ヒートポン プ給湯機の性能評価, 第 22 回エネルギーシステム・経済・環境コンファレ ンス講演論文集, pp. 183〜186, 2006. 1

10）久保田敏史, 浅野良晴, 高村秀紀 : 寒冷地における潜熱回収型ガス給湯 器と $\mathrm{CO}_{2}$ ヒートポンプ給湯機の年間効率に関する研究, 日本建築学会技術報 告集 第 16 巻第 32 号, pp. 201 204，2010. 02

11) IEA, "Promoting Energy Efficiency Investments- Case Studies in the Residential Sector” , 2008

12) Sorrell, S., 0'Malley, S., Schleich, J., and Scott, S. : The Economics of Energy Efficiency: Barriers to Cost Effective Investment, Edward Elgar, Cheltenham, 2004. 11

13) SPRU: "Reducing barriers to energy efficiency in public and private organizations”, Final Report, Joule III Project, EU, 2000.

14）若林雅代，木村宰：省エネルギー政策理論のレビュー一省エネルギー
の「ギャップ」と「バリア」一，電力中央研究所研究報告 Y08046, 2009.5 15）西尾健一郎，岩船由美子，元アンナ：アンケート調査に基づく家庭用エ アコンの利用に係るバリアの分析, 日本建築学会環境系論文集 第 75 巻 第 652 号，517〜 526，2010.6

16）本多則恵: 社会調査へのインターネット調査の導入をめぐる論点一比較 調查実験の結果から一，労働統計調查月報，No. 673，Vo1. 57, 2005.2

17）元アンナ, 西尾健一郎, 岩船由美子 : 給湯器の保有実態と住宅市場セグ メントによる違いの考察, 電力中央研究所研究報告 Y10001, 2010.6

18）元アンナ, 西尾健一郎, 岩船由美子 : 給湯機器の保有・導入に関するア ンケート調査, 日本建築学会大会学術講演梗概集, D-1 分冊, pp. 633-634, 2010.9

19）ヒートポンプ・蓄熱センター：ヒートポンプ・蓄熱白書III, 2009.7

20）住環境計画研究所：2009 家庭用エネルギーハンドブック, 2009.2

21）建設経済研究所・経済調査会：建設経済モデルによる建設投資見通し (2010 年 1 月), 2009.1

22) IEA, "Mind the Gap- Quantifying Principal- Agent Problems in Energy Efficiency” , 2007

23) Meier, A., and Eide, A. : "How many people actually see the price signal? Quantifying market failures in the end use of energy", Lawrence Berkeley National Laboratory, Paper LBNL-63384, 2007.9

24）山下幸人ほか：集合住宅における竣工設備データ，建築設備士，第 40 巻，第 12 号，通巻第 475 号， 2008. 12

注

注 1) 国立環境研究所 (2010)の報告書では, 2008 年度の $\mathrm{CO}_{2}$ 排出量は 12 億 1, 400 万トンであり，1990 年比で 6.1\%増加した。その中でも，家庭部門 は全 $\mathrm{CO}_{2}$ 排出量の $14 \%$ ( 1 億 7, 100 万トン)を占めており, 1990 年比の増加率 も $34 \%$ と，効果的な対策が求められる分野と言える。

注 2) ガス式潜熱回収型給湯器 (通称エコジョーズ) は 2008 年度までの累積 116.2 万台 (2008 年の出荷台数 37.2 万台, ジャパンガスエナジー資料参照), $\mathrm{CO}_{2}$ 冷媒ヒートポンプ式給湯機 (通称エコキュート, 電気式) は 2008 年度ま での累積 152.6 万台 (2008 年の出荷台数 49.5 万台, 日本冷凍空調工業会資 料参照) が導入されたと推計されている。

注 3) 家計調査(総務省)の地域区分にならう(新潟県は北陸, 長野県は関東, 静岡県は東海)。

注 4) 有効サンプルの内訳は, 北海道 : 473, 東北 : 457, 関東 : 946 , 東海 : 472, 北陸 : 470, 近畿 : 476, 中国 : 453, 四国 : 449, 九州 : 463。

注 5) 家計調査 (総務省)をもとに, 単身世帯比率についても, 実態と大きく乘 離しないように, 配布数を調整している。

注 6) 分析にあたり，住宅種類や新築・既築別に給湯器の市場規模を概数で把 握しておく。ヒートポンプ・蓄熱センター(2009)による 2002〜2003 年フロ 一合計では，新築・既築用で約 450 万台/年で推移している。

また，家庭用エネルギーハンドブック (2009)の「新築住宅の建て方別住 宅戸数の推移」によれば，2000～2005 年度の平均の新築住宅戸数は, 戸建 住宅が約 57 万戸，集合住宅は約 61 万戸である。そこでここでは住宅着工 が減少していることも踏まえ(建設経済研究所・経済調査会，2010），新築 住宅の給湯器市場については, 戸建住宅向けを約 50 万台, 集合住宅向けを 約 50 万戸，合計約 100 万台とみなすものとする。

既築住宅向けの給湯器市場については，新築住宅向けを約 100 万台とし て差し引くと, 約 350 万台となる。住宅ストックの構成比 (平成 20 年住宅・ 土地統計調査) が戸建住宅 $58 \%$ ，集合住宅 $42 \%$ あることを踏まえると，既 築・戸建向けで約 200 万台，集合住宅向けで約 150 万台とみなすことがで きる。

注 7) 大手メーカーとは，以下 8 (積水八ウス，大和八ウス工業，ミサワホ 一ム, パナホーム, 積水化学工業 (セキスイハイム), 旭化成ホームズ (へー ベルハウス), 住友林業, 三井ホーム) と調査票では定義した。工務店は「上 記以外の施工会社・工務店」を指す。

注 8）「Q. 設置・交換する前の給湯器の状況として, 最もあてはまるもの をお選びください」という質問に対し，「特に不具合はなかった」の回答 を【不具合前】，「時々不具合が出ていた」，「故障，もしくは，生活に 支障をきたす状態だった」を【不具合後】と分類し，集計した。

注 9）「お住まいを建設した業者，または提携業者」，「当時利用していた給 湯器の業者, または提携業者」を【縁あり】, 「電器屋・量販店・ホーム センター，または提携業者」，「その他のリフォーム業者」を【縁なし】 とした。 